\title{
Ameloblastoma Report of Six Cases with 8 Years follows up (original research article)
}

\author{
Dr parveen .A. lone (Associate professor)
}

\begin{abstract}
Ameloblastoma is an uncommon epithelial odontogenic epithelial neoplasm that is non-mineralized \& locally aggressive.The lesion is often discovered on rotune dental examination. 80\% of ameloblastomas are seen in mandibular molar ramus area.Radiographically ameloblastomas present as well defined unilocular or multilocular radiolucencies with internal bony septa resulting in honeycomb or soap bubble appearence .

Treatment consists of radical surgical resection, as the tumor has a high recurrence rate after incomplete resection. Recurrent lesions have a more aggressive biological behavior than original tumors.

The present study aims to report 6 patients with multilocular ameloblastomas four cases having lesion in molar ramus \& condyle region \& two in anterior region of mandible. All patients were treated by wide segmental resection \& immediate reconstruction was done using reconstruction plates. 8 years follow up was done \& patients are symptom free \& living happily.

Study Design : A Prospective study

Key words: Resection, reconstruction plates, recurrence, odontogenic tumor.
\end{abstract}

\section{Introduction}

Ameloblastoma accounts for approximately $10 \%$ of all tumors that originate in the maxilla \& mandible.[1,2] Ameloblastoma is an intraosseous odontogenic neoplasm of great interest due to its ability to aggressively infiltrate the maxillofacial region. This infiltration may cause sever trauma $\&$ in some cases poss a risk to patients life[3].The estimated incidence of ameloblastoma is approximately 0.5 million population per year.There is no distinct gender predilection. Most cases are diagnosed between 30 and 60 years of age. There are no well established etiologic factors. The posterior region of the mandible is the site of predilection. In approximately $40 \%$ of the cases there is an associated unerupted tooth, often the mandibular third molar. Ameloblastomas may remain asymptomatic before a facial swelling develops .Ameloblastomas may present on conventional radiographs as a unilobular or multilocular corticated radiolucency resembling a cyst. Bony septae may result in a honeycomb appearance. Buccal and lingual expansion is more common in ameloblastoma than in keratocystic odontogenic tumours[.4] Resorption of roots may or may not be present.In the WHO classification of odontogenic tumors a distinction is made between benign \& malignant ameloblastoma .[5] clinically ameloblastoma appears as an aggressive odontogenic tumor ,often asymptomatic \& slow growing with no evidence of swelling. It can sometimes cause symptoms such as malocclusion, swelling pain \& paresthesia of the affected area.[6] It spreads by forming pseudopods in marrow spaces without concomitant resoption of the trabecular bone.As a result, the margins of tumor are not clearly seen on radiograph or during surgery \& tumor frequently recurs after in adequate surgical removel7].Ameloblastoma is divided into three clinico radiologic groups, solid or multicystic, unicystic \& peripheral. The solid ameloblastoma is the most common form of the lesion $(86 \%) \&$ is more aggressive Than other types \& has higher incidence of recurrence[8].unicystic ameloblastoma has a large cystic cavity with luminal, intraluminal or mural proliferation of ameloblastic cells \& is less aggressive with low rate of recurrence $[9,10]$

Tumors occurring in the maxilla are usually located in the third molar area and may extend into the floor of nasal cavity, paranasal sinuses, orbit, nasopharynx or skull base. Treatment of mandibular ameloblastoma remins controversial. Treatment consists of wide resection, curettage, \& enucleation[ 11] Recurrence rate is $15 \%$ to $25 \%$ high after radical treatment \& $75 \%$ to $90 \%$ after conservative treatment [12]

\section{Material \& methods}

In this study 6 patients were selected who were diagnosed, treated in Oral \& maxillofacial surgery department of Indira Gandhi Govt dental college Jammu \& had completed 8 years of follow up. The information regarding age, gender, localization duration of the lesion was noted .Incisional biopsy was done to confirm the diagnosis. Radiographically all the patients had multilocular radiolucencies. Hemi mandibulectomy with disarticulation was done in four patients followed by reconstruction by reconstruction plate .In anterior region segmental resection was followed by reconstruction plate in two patients. Ragular follow up was done by clinical \& radiographic examination for 8 years. In view of small no of patients no statistical analysis was made. 
Case 1

.A 22 years old female reported to oral \& maxillofacial surgery department with a gross facial swelling on rt side with no pain (fig 1)Swelling was extending from body of mandible to temporo-mandibular joint region. Swelling was mult inodular extending to neck. Intra orally there was expantion of buccal \& lingual cortical plates in molar pre molar \& ramus region \& 2 nd molar was carious exposed \& tender . (fig2). OPG radiograph revealed multi locular radiolucent lesion involving body ramus, condyle, resoption of roots \& lower border of mandible was eroded.(fig3)., Patient was $6^{\text {th }}$ month pragnant Incisional biopsy was done, $2^{\text {nd }}$ molar was extracted histopathology confirmed plexiform ameloblastoma. Patient was advised to report for surgery after delivery \& after 6 months of delivery patient reported back. Hemi mandibulectomy with disarticulation ,using lip split incision was done under general anesthesia \& immediate reconstruction was done using reconstruction plate with condylar head.( fig 4,5,6 7).

Patient after 3 years gave birth to $2^{\text {nd }}$ child $\&$ anesthetist sought our clearance regarding any problem to plate during intubation or extrubation .

Patient is still in follow up \& has completed 8 years (fig 8). Since patient was very poor she was referred for monthly scholarship from social welfare department .

Case $2 \& 3$

One Patient 50 years old \& other 35 year males had swelling in anterior mandible extending from $2^{\text {nd }}$ pre molar on left side to first molar on right side .Swelling was involving lingual ,buccal cortex $\&$ also inferior border of mandible. Histopathology confirmed accanthomatous type of ameloblatoma. Wide segmental resection involving $1.5-2 \mathrm{cms}$ normal healthy bone was done \& immediate reconstruction done using reconstruction plates. Fig 9-16)

\section{CASE 3 Figs 1718 \\ \&}

\section{CASE $4 \quad$ Figs $19-23$}

One patient 38 years \& other 42 years old females reported with gross swelling on right side of face extending from body of mandible to condylar region .one patient had intraoral mucosal perforation.radiographically both revealed multi locular radiolucencies .Histopathology confirmed follicular type of ameloblastoma. Hemi mandibulectomy along with disarticulation was done with lip split incision \&immediate reconstruction was done using reconstruction plates. Patients are in our follow up \& $9^{\text {th }}$ year going on .Patients are satisfied with only little bothered about depression on cheek.

\section{CASE $5 \quad$ Figs $\quad 24-29$}

III. Images Of 5 Patients

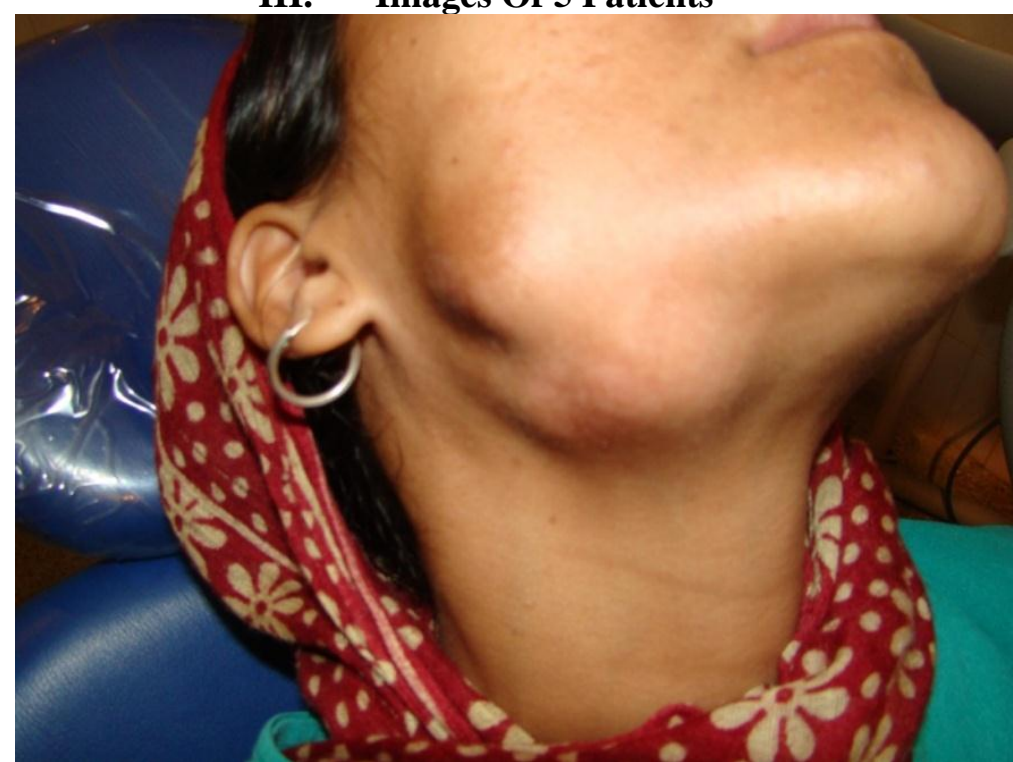

Fig 1 Pre operative photograph showing multi nodular swelling 


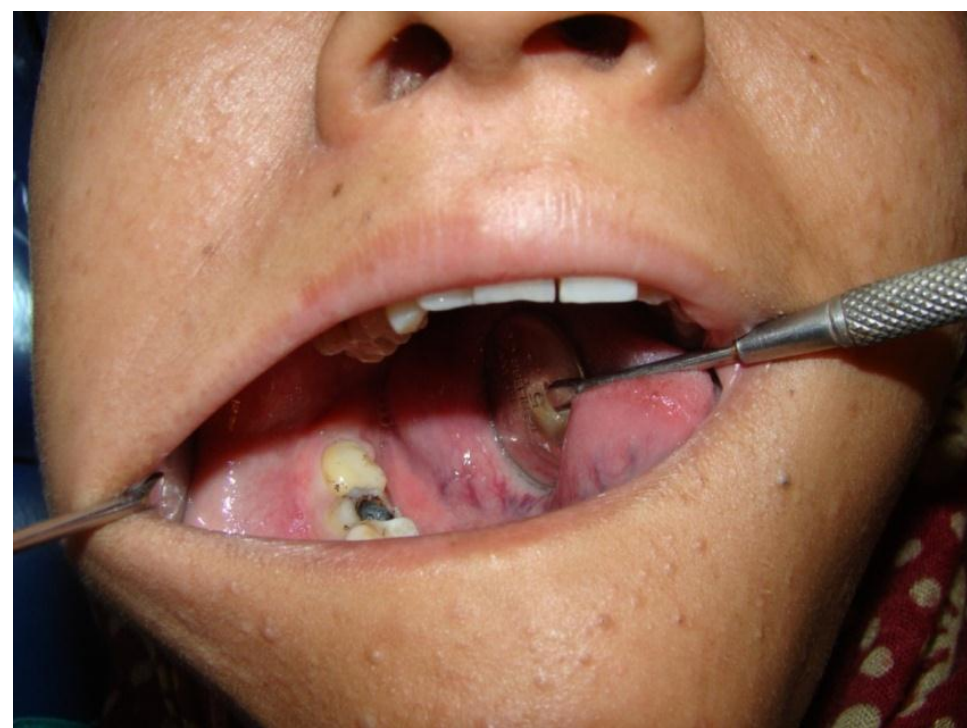

Fig 2 pre op photo showing carious $2^{\text {nd }}$ molar

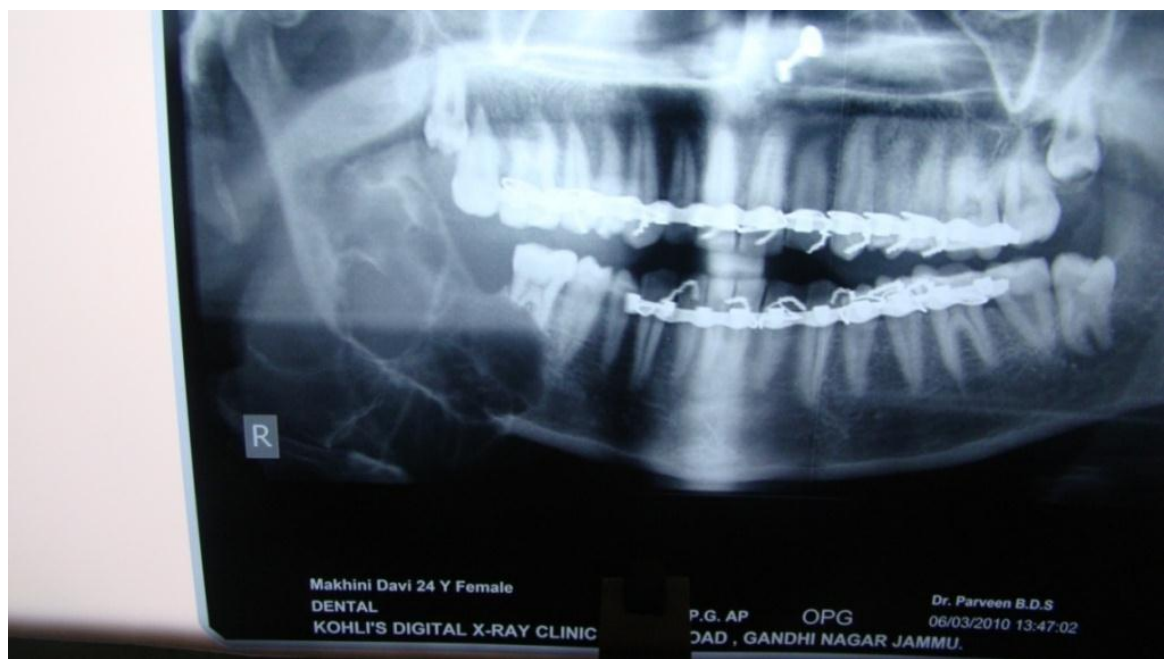

Fig 3 radiographic multi nodular appearance involving body ramus condyle

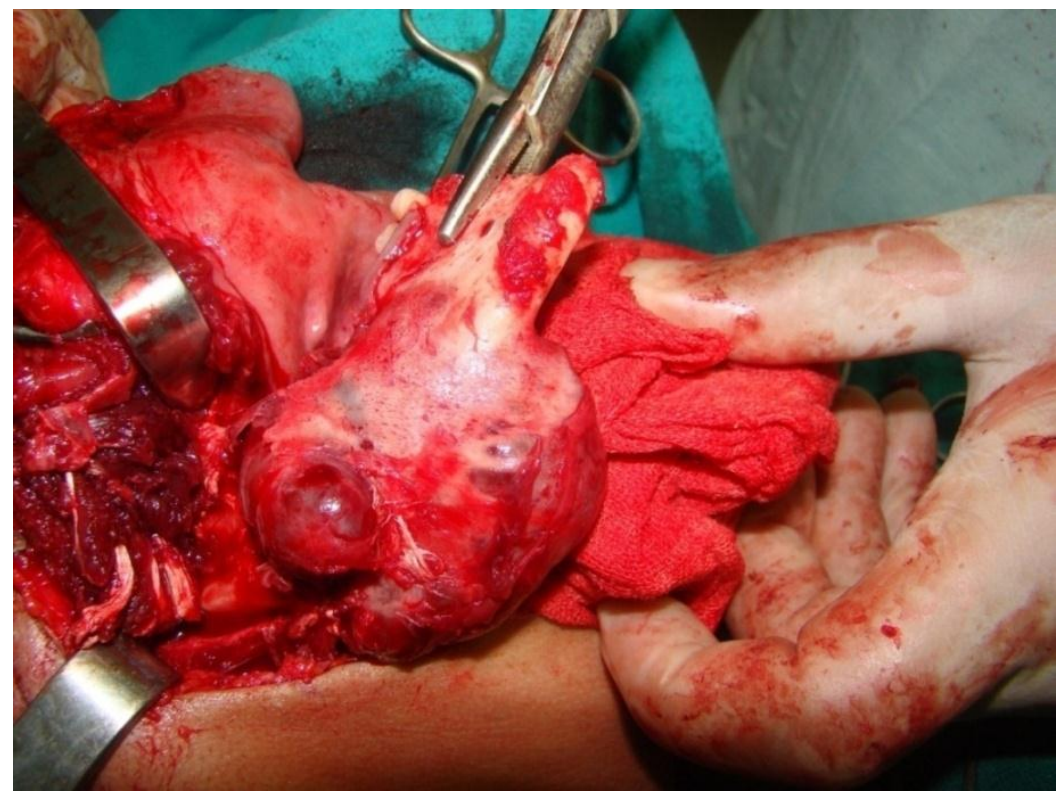

Fig 4 Tumor being removed 


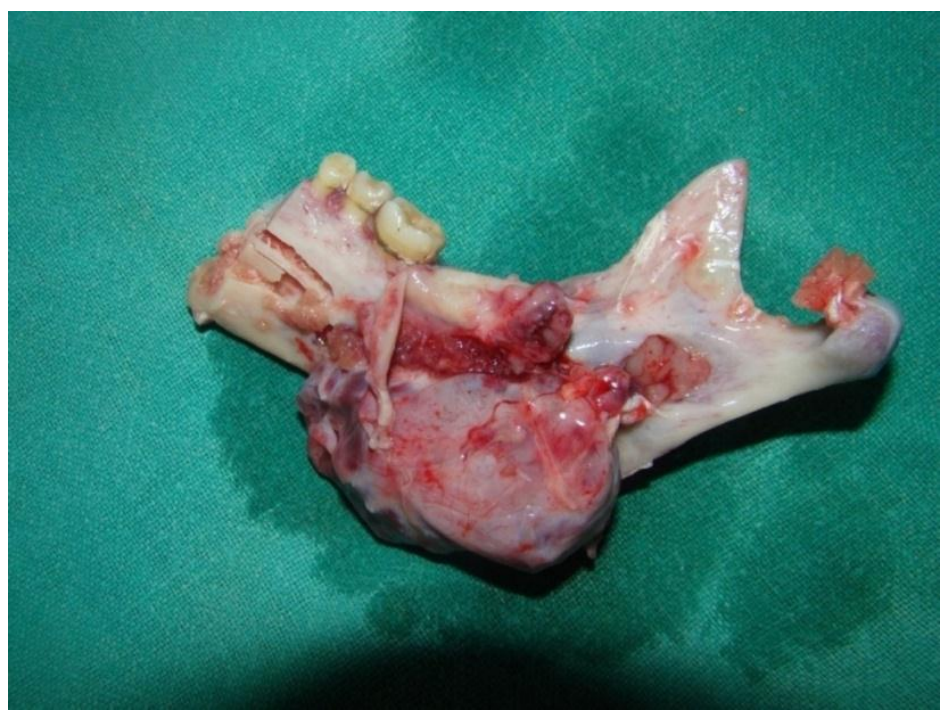

Fig 5 Resected specimen

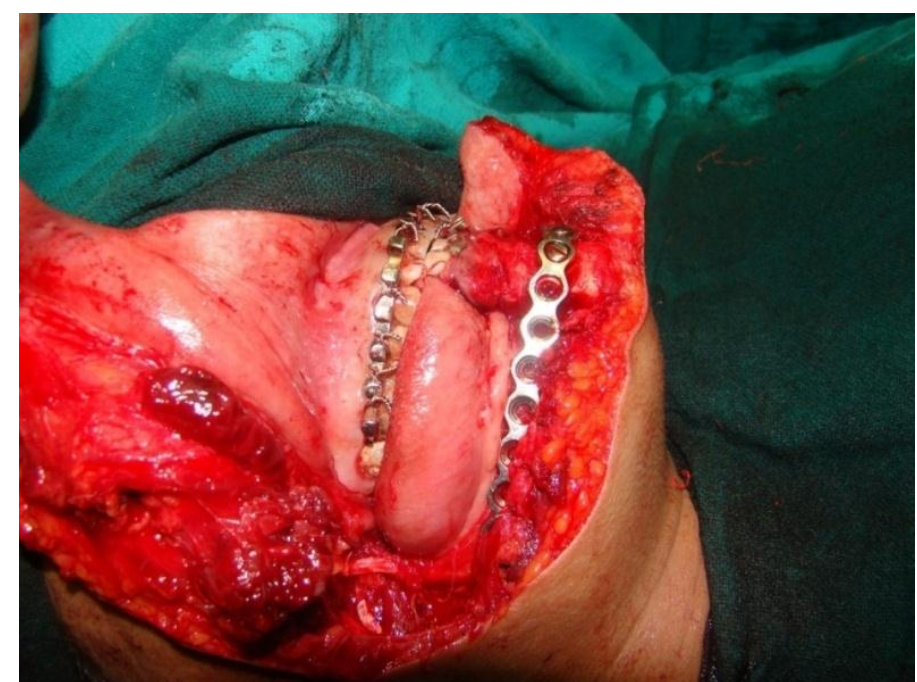

Fig 6 Reconstruction done using reconstruction

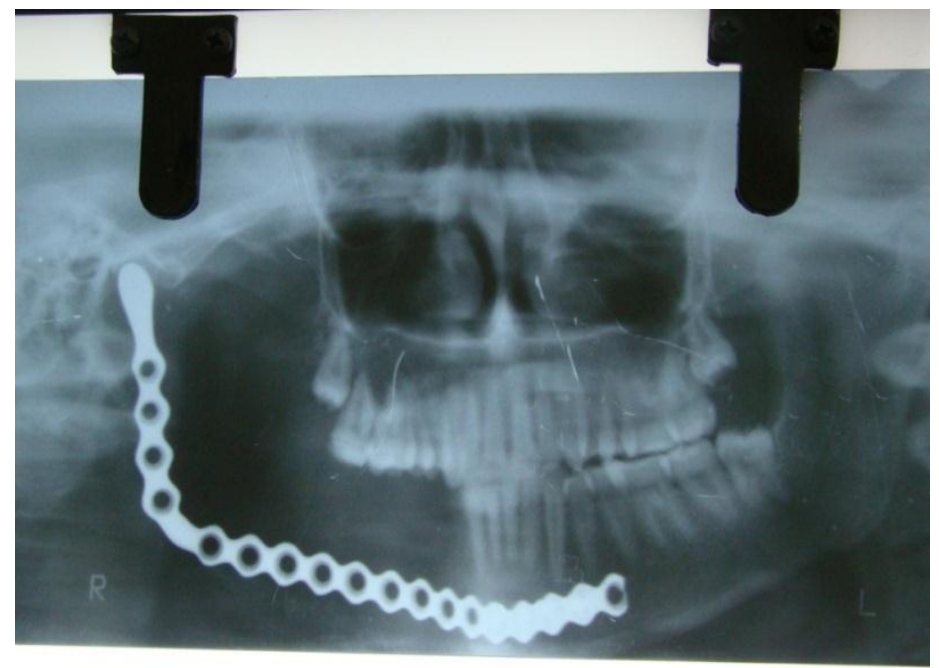

Fig 7 Post operative radiograph showing reconstruction plate 


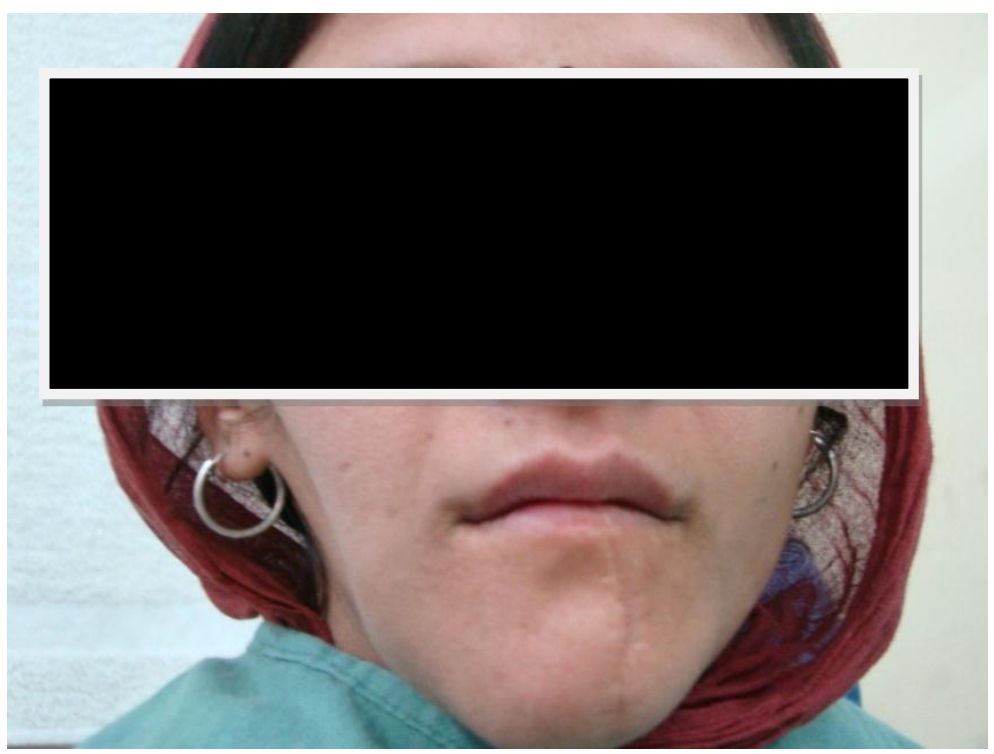

Fig 8 Post op Photograph after 9 years

Case 2

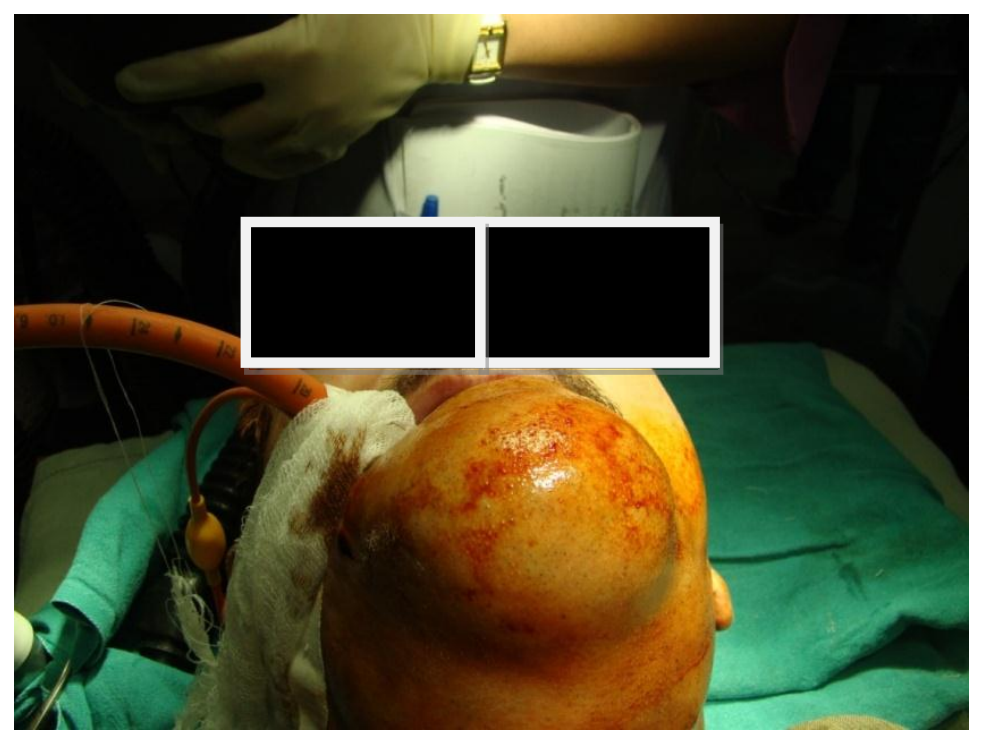

Fig 9 Pre op photo prepared for anterior segmental resection

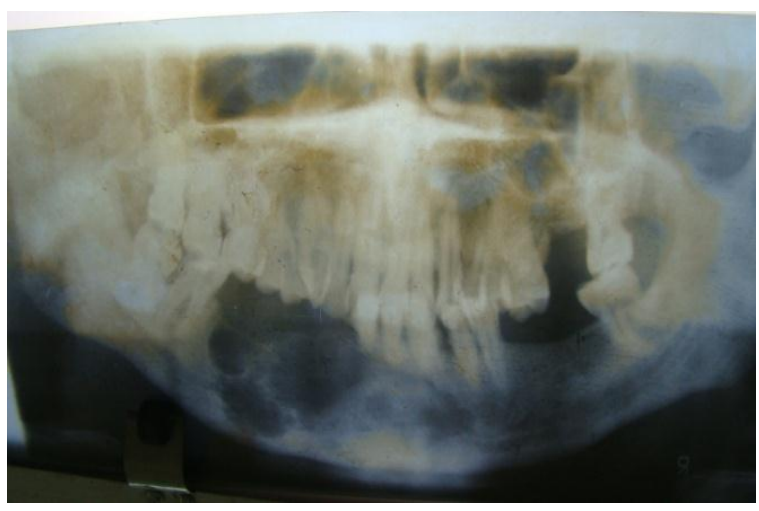




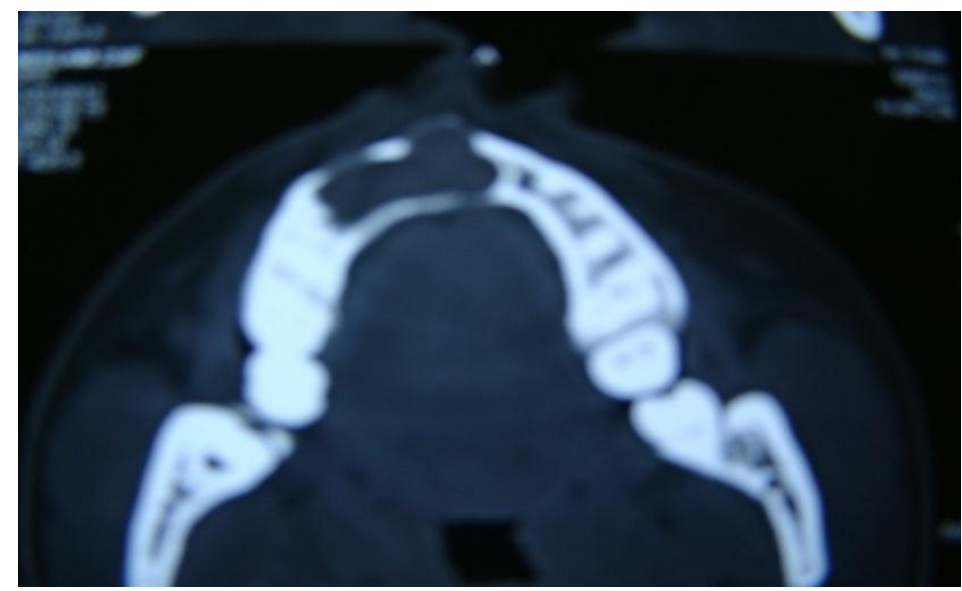

Fig 10 Pre op OPG \& CT scan

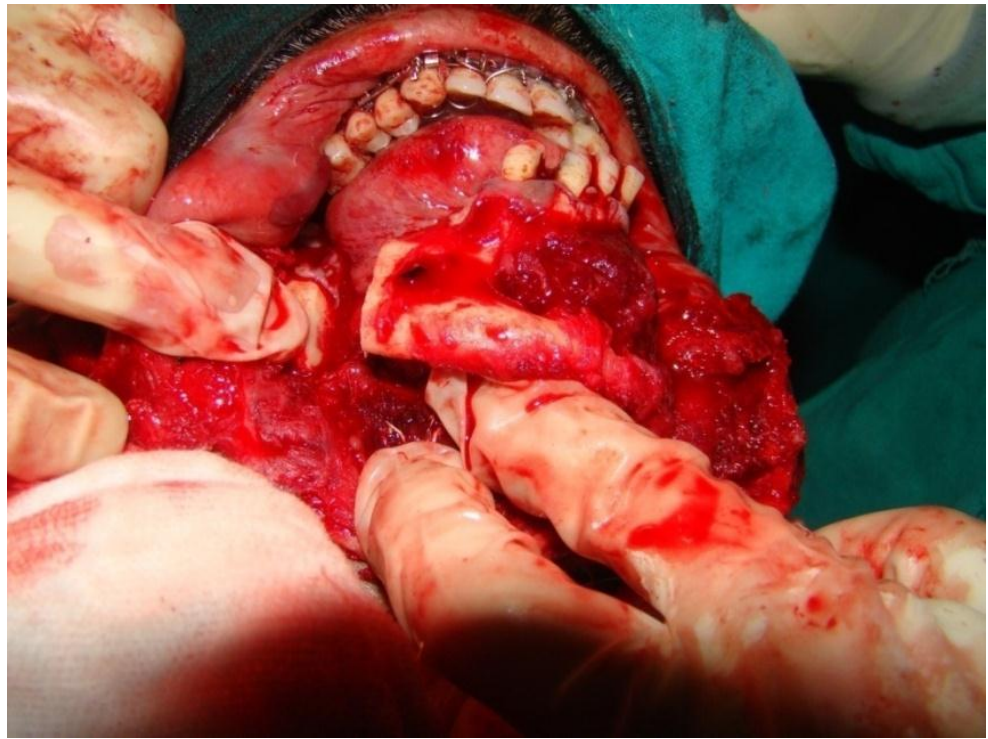

Fig 11 Anterior segmental resection being done

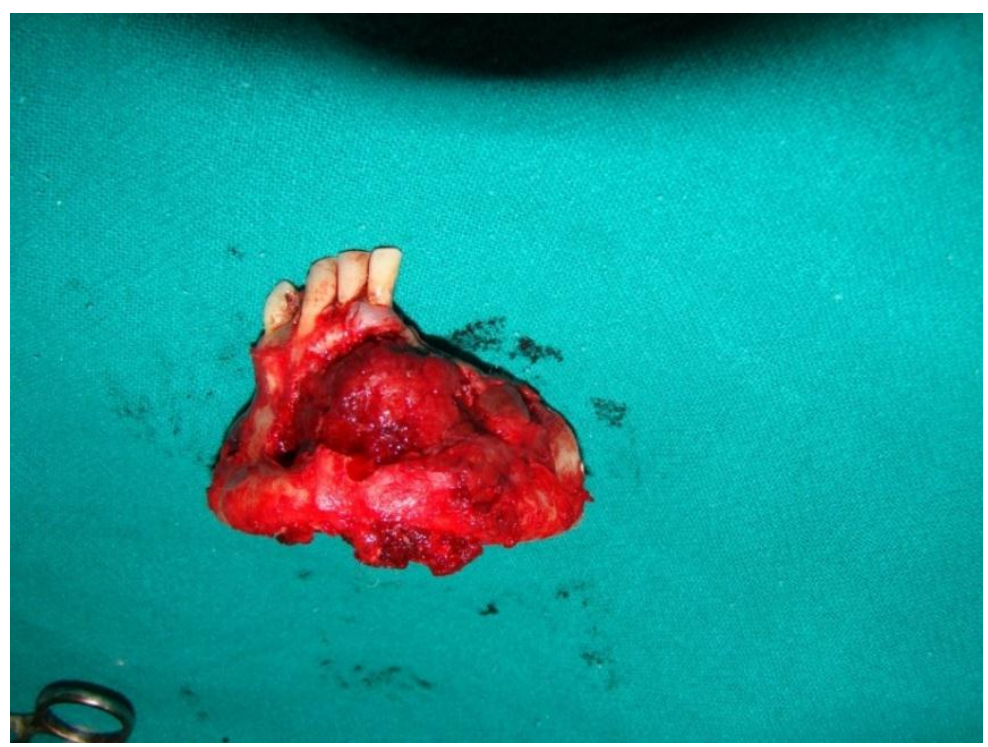

Fig 12 Resected anterior mandibular specimen 


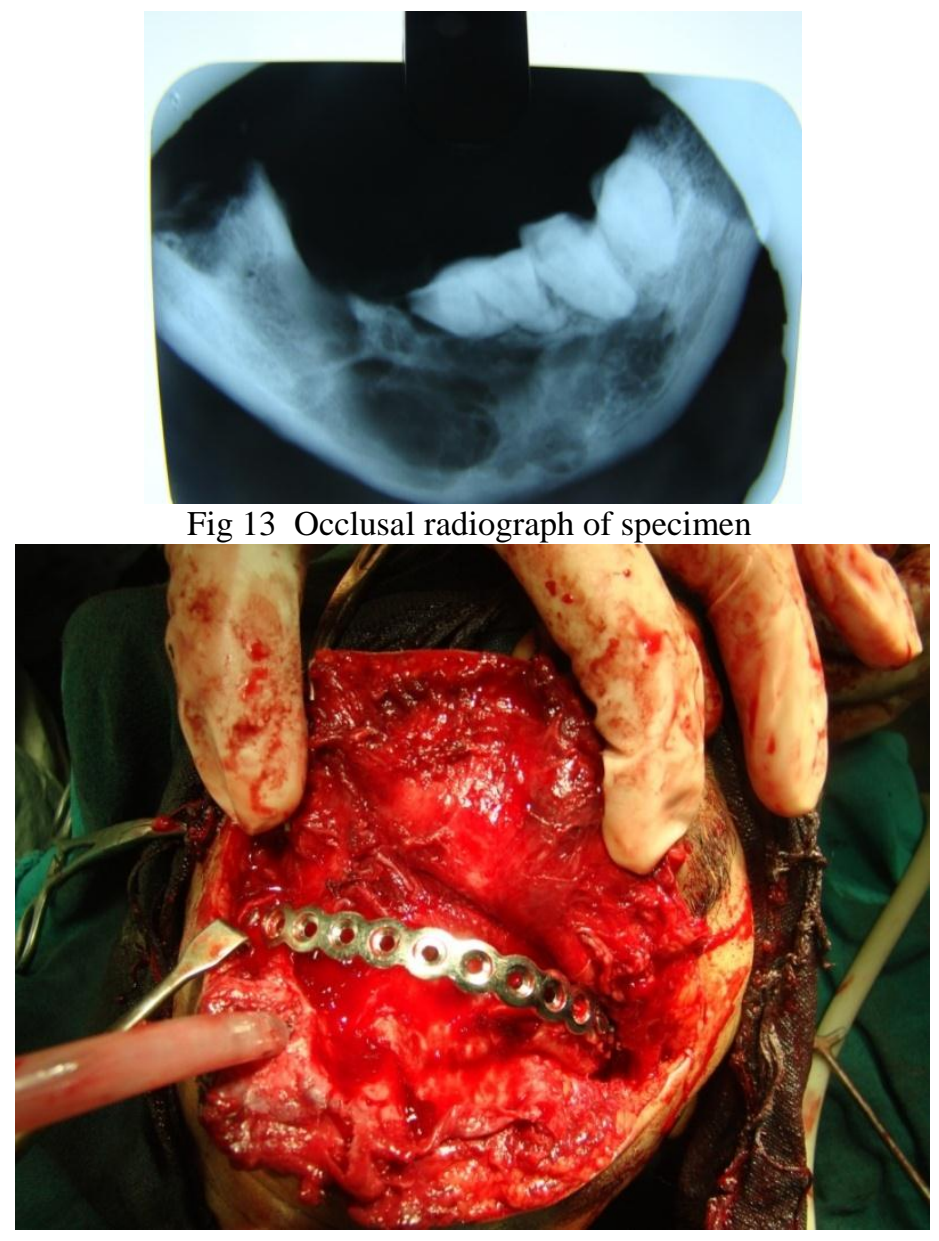

Fig 14 Reconstuction plate fixed

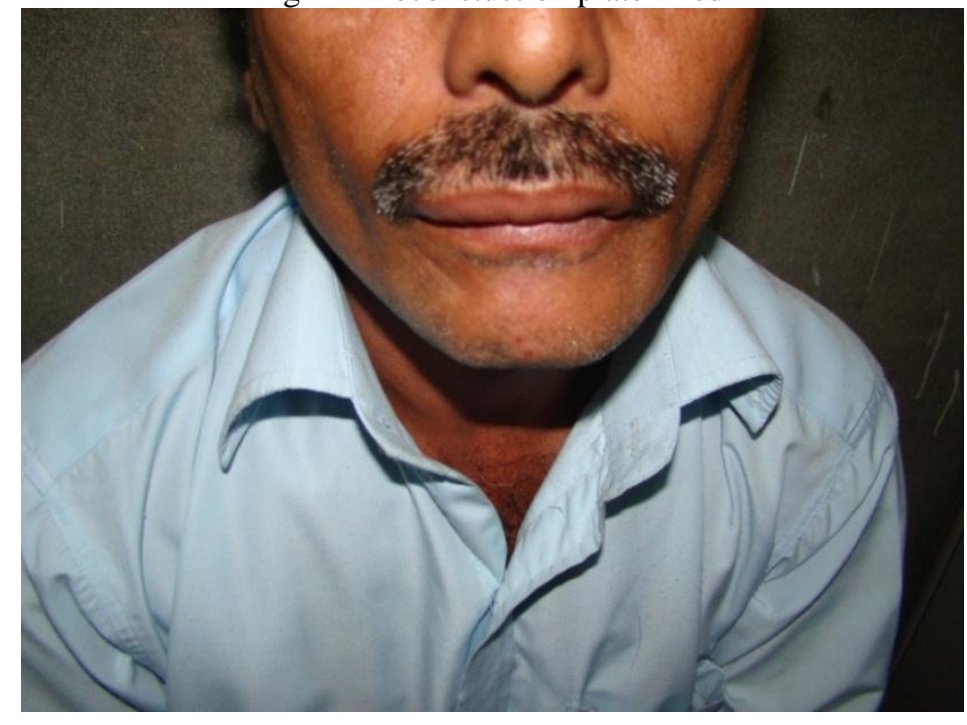

Fig 15 Post op Radiograph 


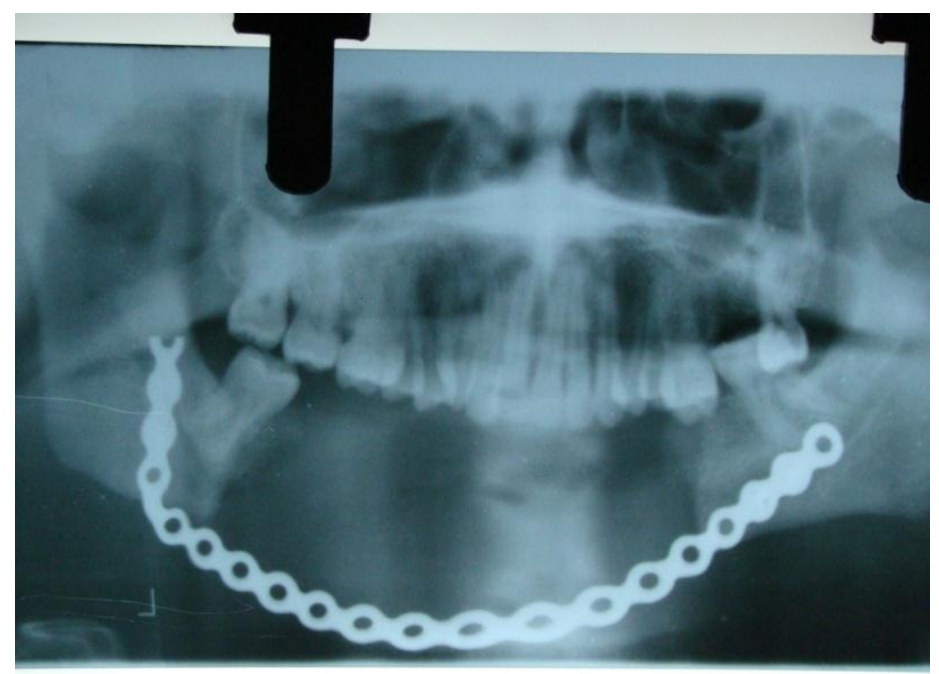

Fig 16 Recent Post op photograph after 8 \& half years

Case 3

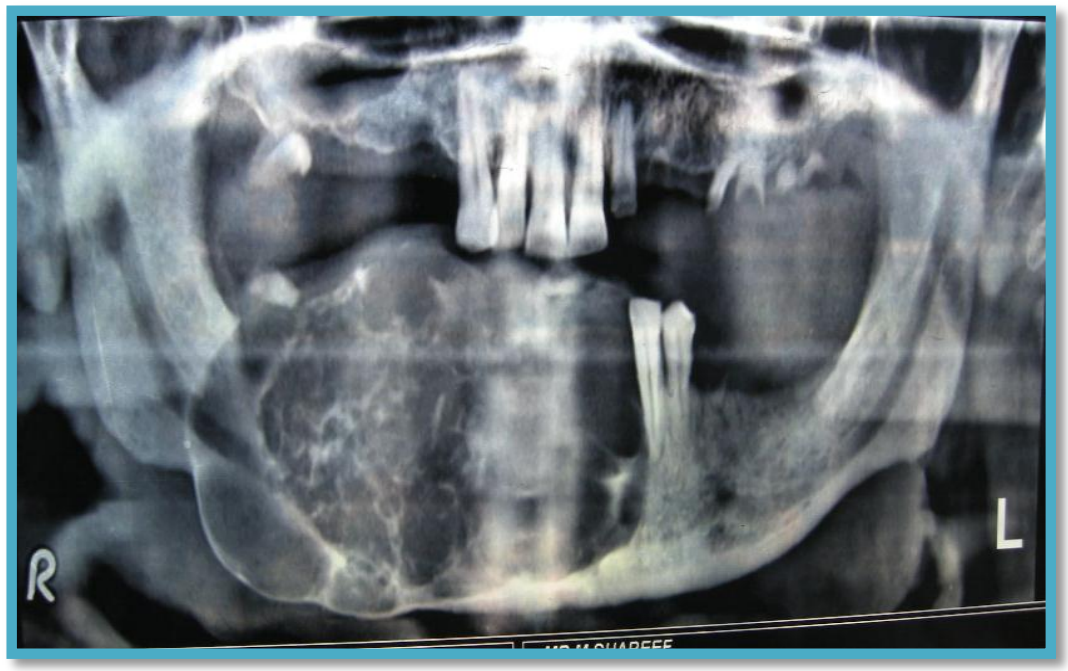

Fig 17 Pre operative Radiograph showing lesion

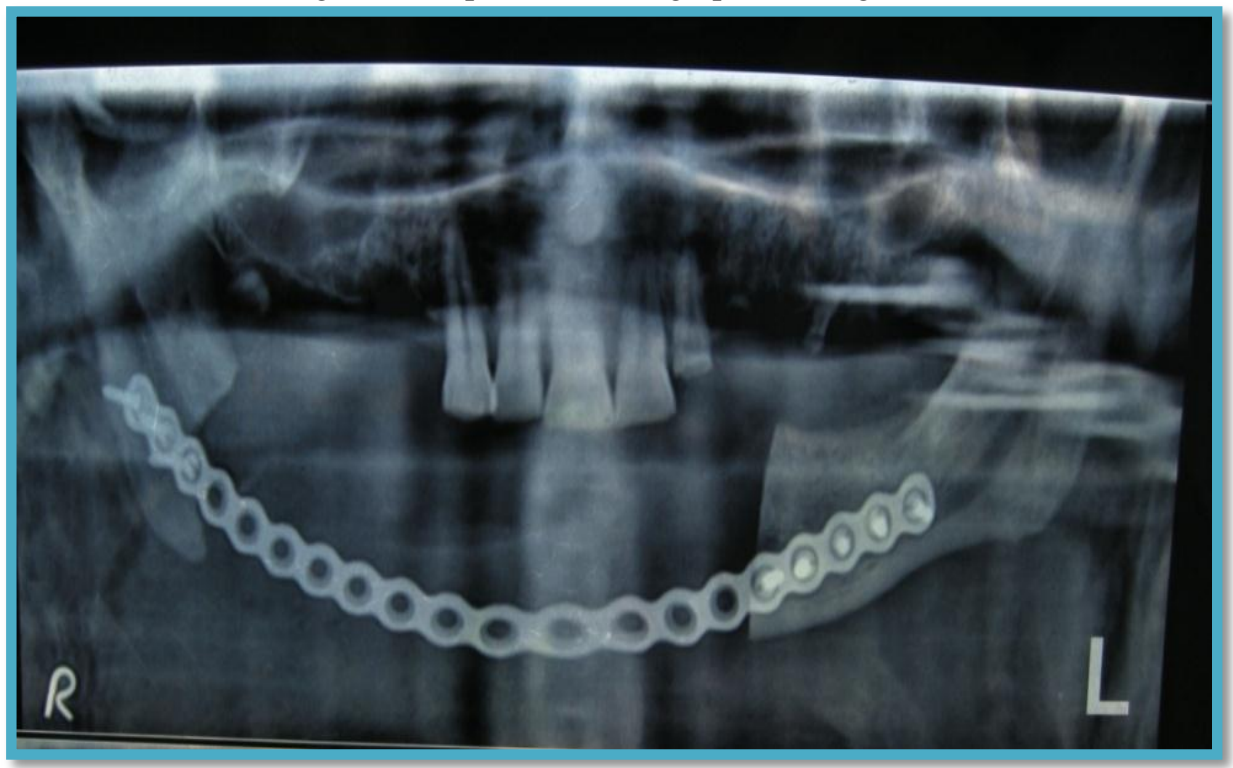

Fig 18 Post op radiograph showing reconstruction plate 
Case 4

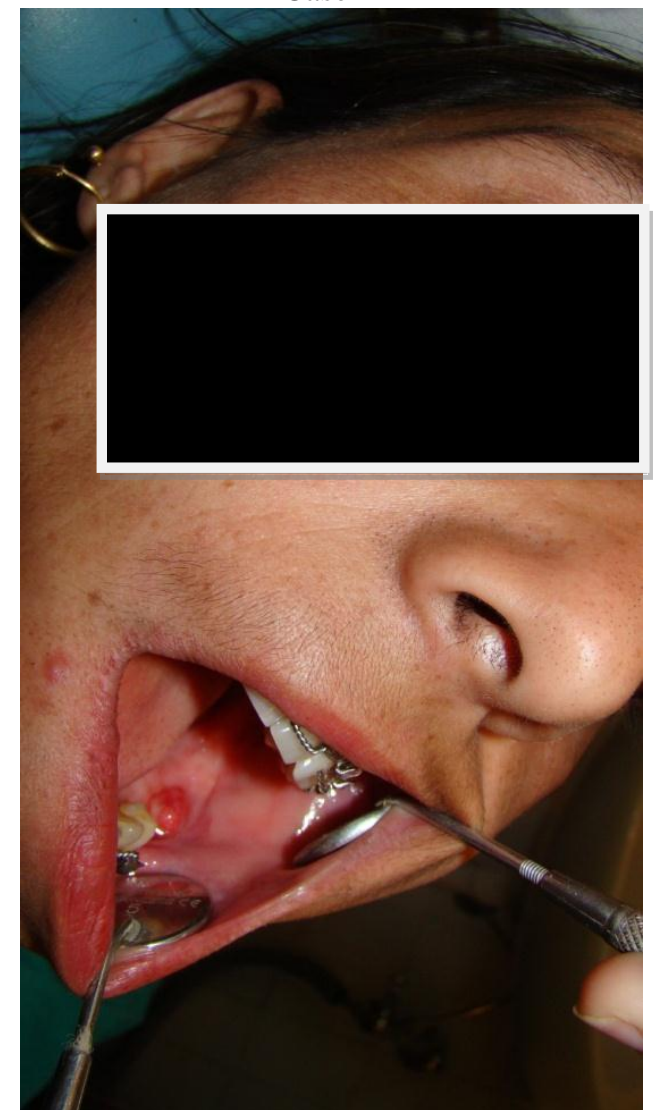

Fig 19 Pre op photo showing intra oral lesion

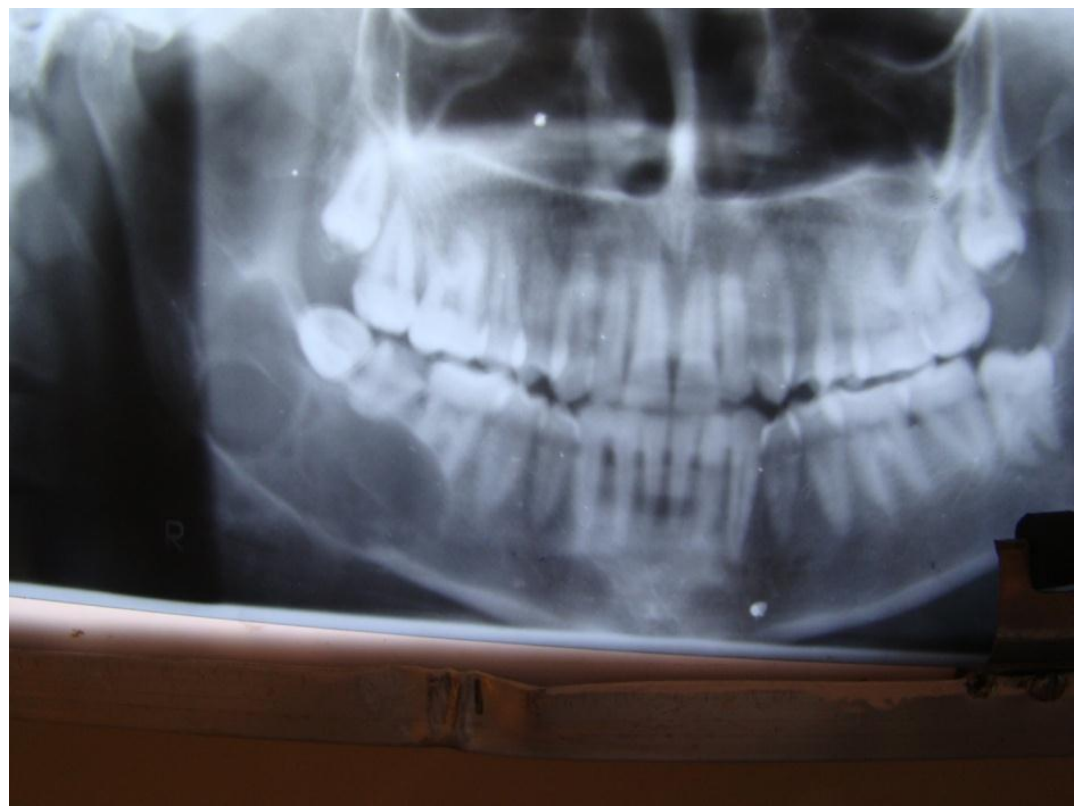

Fig 20 Pre op radiograph 


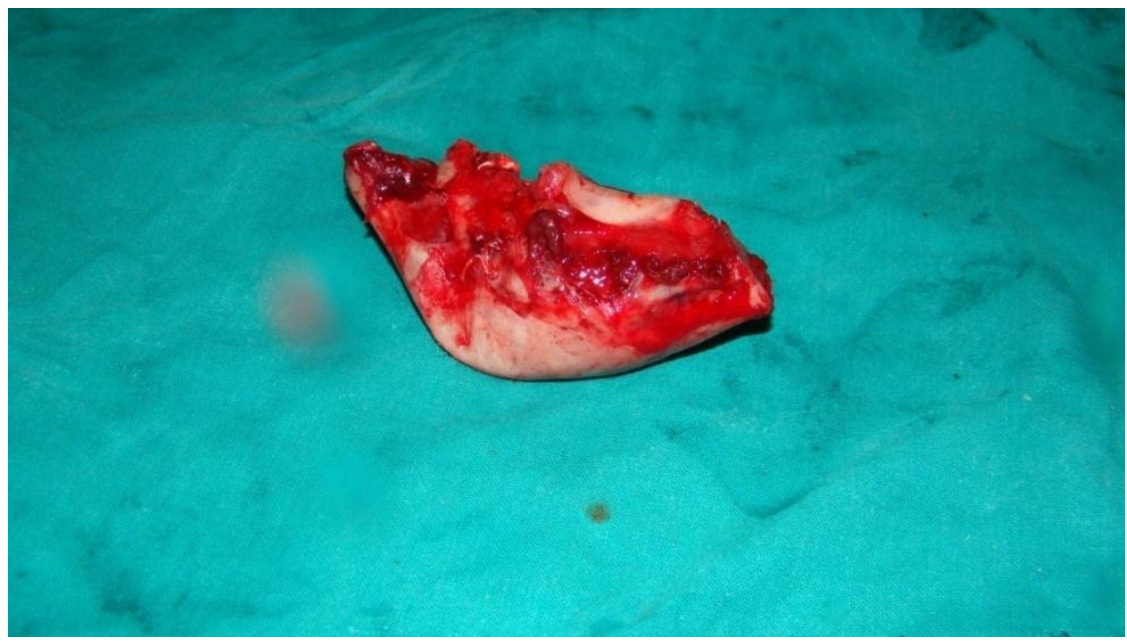

Fig 21 Resected specimen

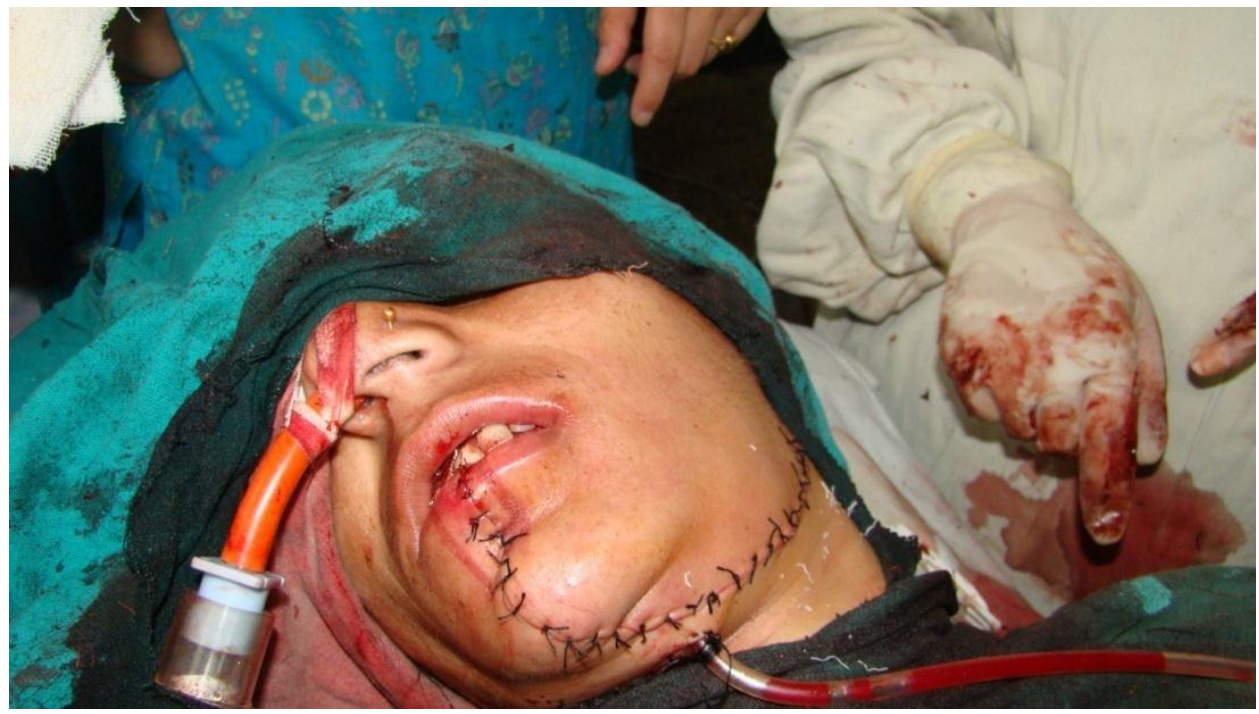

Fig 22 intra op photograph after suturing

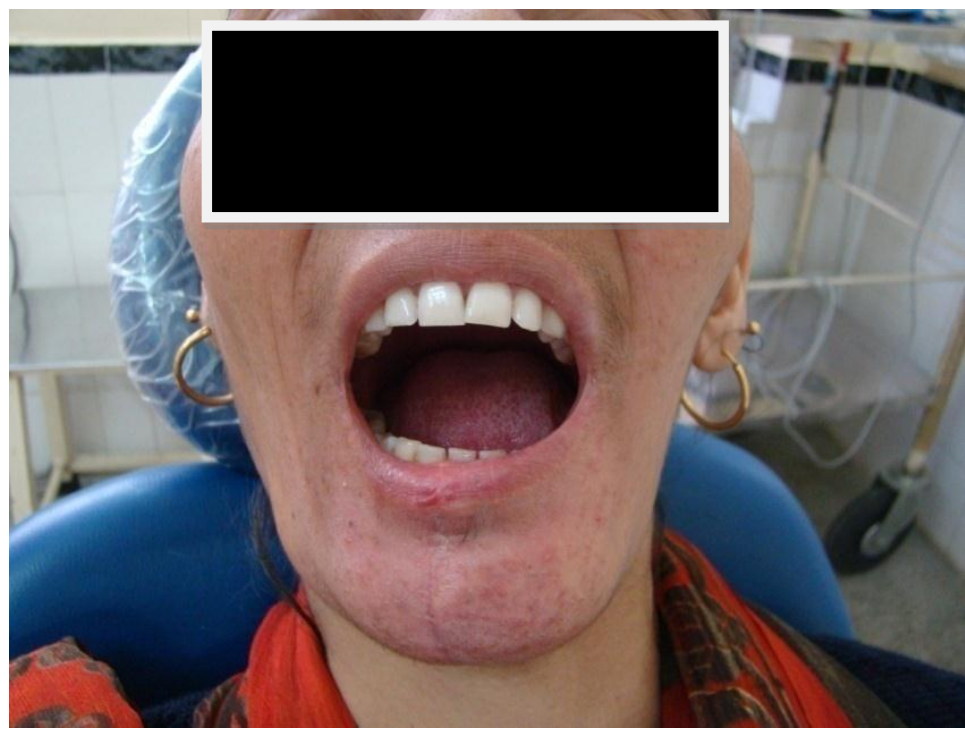

Fig 23 Post op photo after 7 years 


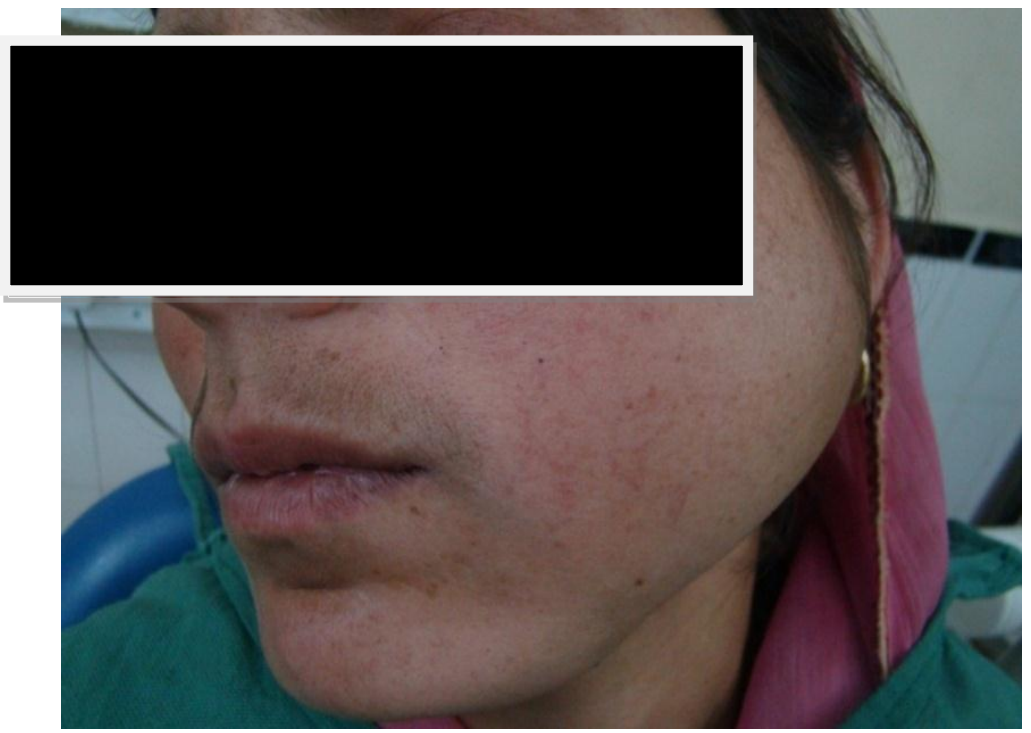

Fig 24 Pre operative photograph lateral profile

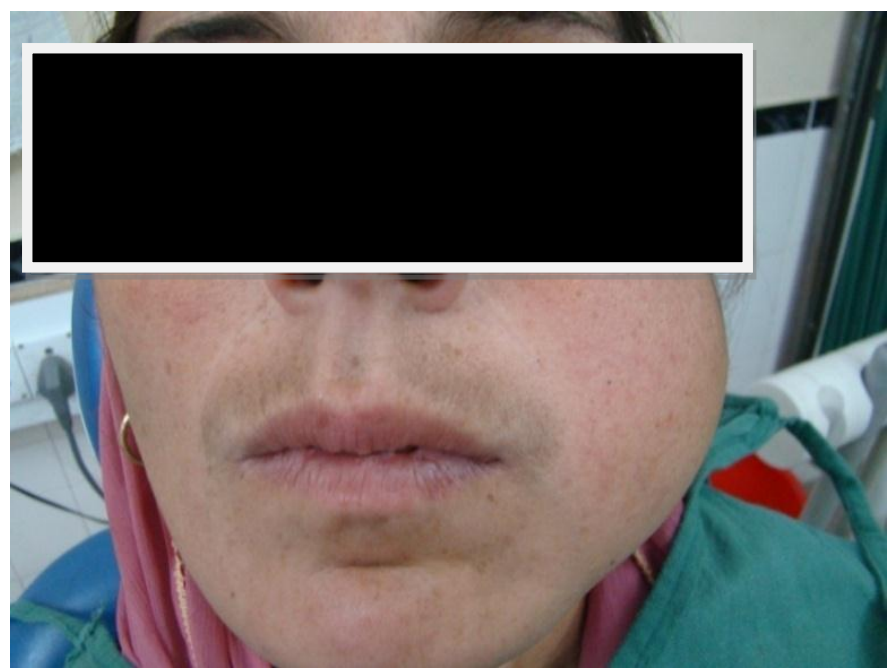

Fig 25 Pre operative photograph showing swelling frontal profile

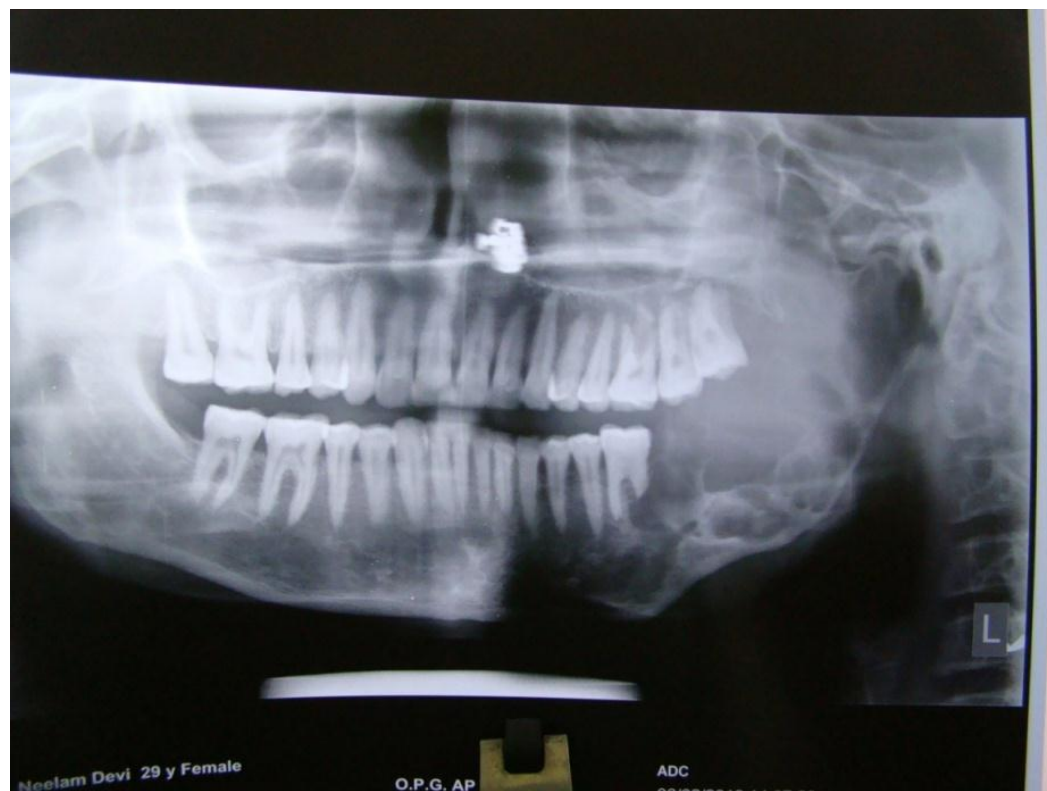

Fig 26 Pre op radiograph showing bone destruction 


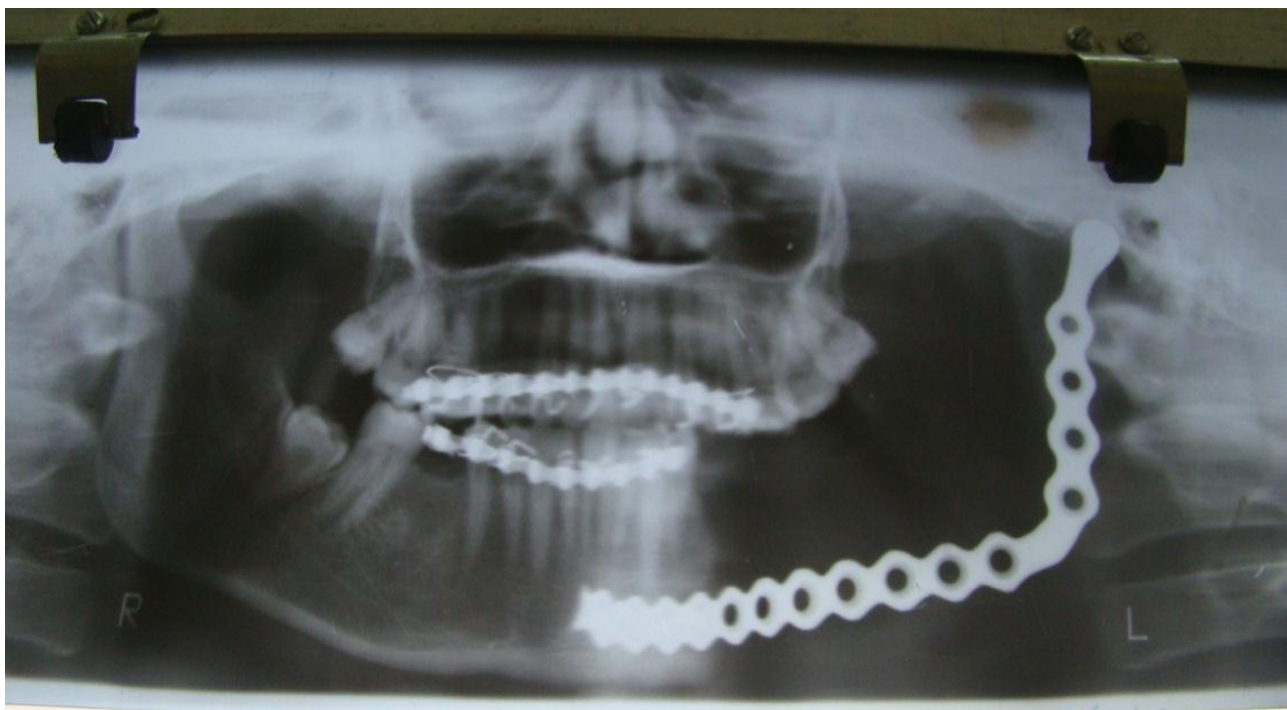

Fig 27 Post op radiograph showing reconstruction plate

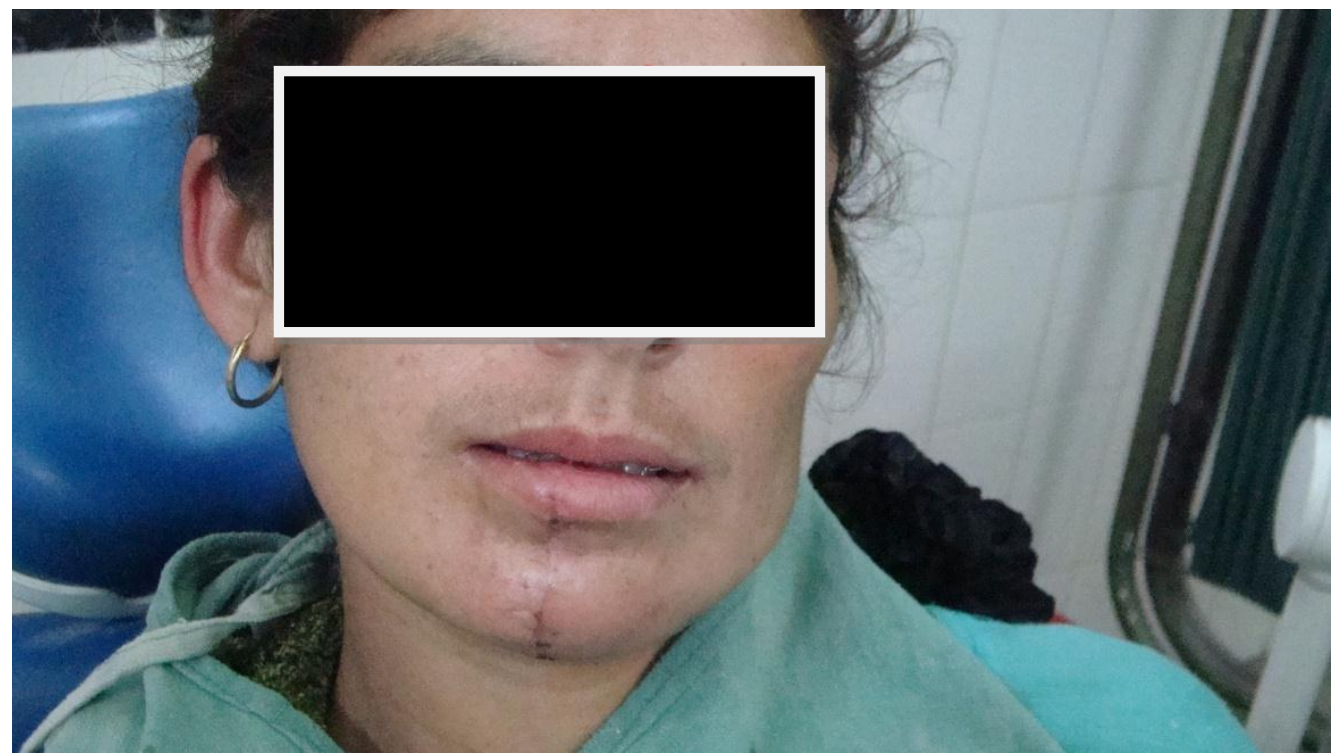

Fig 28 post op photo after 1 month

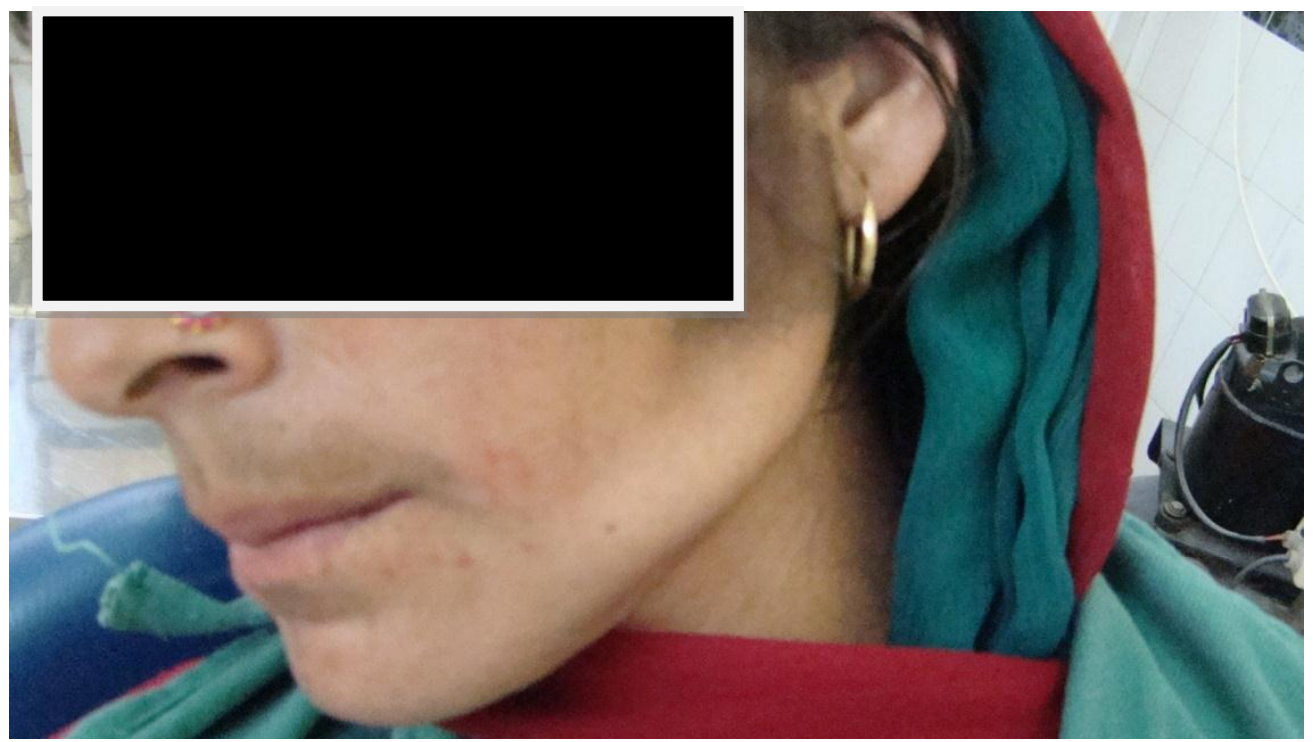

Fig 29 recent Post op photograph lateral profile 


\section{Results}

In this study 6 cases were selected ,three were females \& three were males. Age ranged from 22 to 50 years. In the four patients the lesion was located on posterior side of mandible two left side two on right side . Two patients had lesion was present in anterior mandible.In all the cases extra oral deformity/facial asymmetry was present .swellings were painless. . Radiography revealed large multi locular radiolucencies. The cortical bone was very thin. Periosteal perforation was seen in two patients. In all the four cases ramus, body, angle condyle \& were affected, only head of condyle \& coronoid process were spared there was resoption of roots of posterior teeth with mobility. These patients were treated by hemi mandibulectomy with disarticulation \& reconstruction plates .In two patient extra oral swelling was present in anterior region from right side mandibular premolar to first molar on left side, segmental resection was followed by immediate reconstruction by reconstruction plates. Follow Up was done on annual basis on clinical \& radiographic findings for 8 years .No recurrence was noted in any of the patient.

\section{Discussion}

Ameloblastoma is a tumor with a well known propensity for recurrence [9]It originates from epithelial remnants of dental embyogenesis, without the participation of odontogenic ecto mesenchyme Martinez et al[121] This tumor was initially considered as a type of odontogenic cyst \& was first described by Cusak [13] in a case of mandibulectomy \& latter reported by Broca[14]\& Falksson[15].The classic Study by Malassez [16] ultimately differentiated the tumor from other types of cyst \& named it Adamantinoma. The term ameloblastoma was latter suggested by Ivy \& Churchill [17] based on odontogenic epithelium involvement in the tumor origin.

Adekeye \& Lavery [18] have reported age range from from young adults to $4^{\text {th }}$ or $5^{\text {th }}$ decade of life .The present study also report patients of ameloblastoma from 22 years to 50 years of life

Ameloblastoma can occur at any location in maxilla or mandible \& most prevalent location is mandibular posterior region (80\%) reported by Becelli Richart \& .Martinz [1,3,12] In the present study two patients had lesion in anterior region involving symphysis ,parasymphysis region.four lesions were in posterior mandibular region

Ameloblastomas are classified as multicystic $86 \%$ and unicystic $13 \%$ \& peripheral or extra osseous $1 \%$.In addition malignant ameloblastoma with metastasis very rarely seen reported by Antunes et al[19].Radiographic \& clinical distinctions are important because the treatment for unicystic can be conservative due to its less aggressive behavior \& small size than multicystic type shown by Ordet et al[20] in his studies. In the present study we have chosen only multicystic/multilocular ameloblastomas for reporting

.Radiologically ameloblastoma appear as a radiolucent lesion that may either have unilocular or multilocular appearance. It may expand the cortical plates which give rise to paper thin \& soap bubble appearance on panoramic radiograph as well as C.T. scan reported by Bilkay et al [21]

In the present all the radiograph showed radiolucent lesions involving both buccal \& lingual plates and lower border of mandible with poorly defined borders. . Soap bubble appearance or honey comb appearance was seen on OPG .\& diagnosis was done on histopathologic examination. The histopathology of ameloblastoma consists of proliferation of cells arranged in variable pattern .The most frequent pattern is follicular subtypes reported by Mendenhall et al[ 22]. Accanthomatous type, granular cell, basel cell \& desmoplastic .In plexiform pattern interdigitating cords \& irregular masses of epithelial cells surrounding small amounts of stroma of stellate reticulum can be seen. The granular pattern is an aggressive lesion with significant tendency to recur,\& neoplastic epithelial components exhibit cells with a finely granular cytoplasm. The basel cell ameloblastoma is the least common type \& is composed of nests of uniform basaloid cells . Desmoplastic pattern exhibit the formation of a densly collagnized stroma with several fibrous type Antunes et al[19]

In the present study two ameloblastomas were accanthomatous type $\&$ three were follicular type $\&$ one was plexiform type. Both accanthomatous type lesions were seen in anterior mandible region.

Large tumors may rupture the bone cortex \& infiltrate adjacent soft tissue on lingual surface of mandible reported Pizer et al [23] where as in the present study two tumors had eroded mucosa on alveolar edentulous ridge in mandibular posterior region.

A high recurrence rate between $50 \%$ to $90 \%$ after conservative treatment. Several authors have supported surgical resection with safety margins for the treatment of solid multicysti c ameloblastoma \& have advocated bone resection in the affected area with at least $1.5-2 \mathrm{Cm}$ of healthy tissue beyond radiographic borders of the lesion reported by Anjos et al \&;Martinez et al[ 24,12]

Four patients in present study were treated by hemi mandibulectomy with disarticulation. Two patients had lesion in anterior region accanthomatous type \& were treated by segmental resection involving $1.5-2 \mathrm{~cm}$ 
normal healthy bone in accordance with Chana et al [25] who stated that conservative therapies of these tumors like enucleation \& curettage are strongly discouraged as they lead to almost inevitable recurrence

.Lip split incision was used to expose tumor in all the cases .supported by Derderian et al [26] who has recommended choice of treatment surgical excision with free margins .The traditional approach for mandibulectomy is through lip splitting incision which gives a better exposure for complete tumour removel .

Reconstruction of the large mandibular defect represent a challenge to head \& neck surgeons. The functions of mandible include facial appearance, chewing, speech\& swallowing The challenge in the management of large ameloblastoma of the mandible is not only to excise tumor completely in order to prevent recurrence but also to provide the best reconstruction. There are many methods of reconstruction reported in literature for reconstruction of mandible $\&$ microvascular surgery is the preferred one .

In the present series immediate reconstruction was done using mandibular reconstruction plate in accrodance with Akhairi et al [27] in his case study.

Eppley et al [28] in his review have shown that there was no recurrence in those cases treated by en block resection as compared to enucleation \& curettage in which recurrence rate is as high as $25 \%$ to $50 \%$.

In series reported from south korea the follicular, granular cells,\& accanthomatous type had high likehood of recurrence .The chance of recurrence seems to be more dependant on the method of surgical treatment rather than histologic subtype reported by Ghandhi et als [29].

IN the present study all the 6 patients completed 8 years of followup .No significant complaint was given by any patient except small depression on cheek .ALL the patients three males $\&$ three femles are living happily One patient was operated when she had 6 months old child..No recurrence clinically or radiographically was seen .In general annual follow up of 10 years is recommended

.Conclusion

.In this article we have experienced that when multi locular radiolucent tumor has involved both buccal, lingual cortices \& lower border of mandible, wide segmental resection with safety margins of healthy tissue $1.5-2 \mathrm{cms}$ beyond radiographic margins of the lesion should be done .Immediate reconstruction by reconstruction plate can be the treatment of choice especially when logistics etc for microvascular surgeries are not available . Reconstruction plate can be kept for longer time if it does not show dehiscence ,infection migration or loose hardware breakage. A long term follow up both clinically \& radiographically is important.

\section{Bibliography}

[1]. Becelli, R.; Carboni, A.; Cerulli, G.; Perugini, M. \& Iannetti, G. Mandibular ameloblastoma: analysis of surgical treatment carried out in 60 patients between 1977 and 1998. J. Craniofac. Surg., 13:395-400, 2002. [ Links ]

[2]. Zemann, W.; Feichtinger, M.; Kowatsch, E. \& Kärcher, H. Extensive ameloblastoma of the jaws: surgical management and immediate reconstruction using microvascular flaps. Oral Surg. Oral Med. Oral Pathol. Oral Radiol. Endod., 103:190-6, 2007. [ Links ]

[3]. Reichart, P. A.; Philipsen, H. P. \& Sonner, S. Ameloblastoma: biological profile of 3677 cases. Eur. J. Cancer B Oral Oncol., 31B:86-99, 1995. [ Links ]

[4]. Voorsmit RACA. The incredible keratocyst. A retrospective and prospectivestudy. Academic Dissertation, University of Nijmegen; 1984.

[5]. Barnes L, Eveson JW, Reichart PA, Sidransky D. World Health Organization Classification of Tumours. Pathology and Genetics. Head and Neck Tumours. Lyon: World Health Organization International Agency for Researchon Cancer, IACR Press; 2005.

[6]. Becelli R, Carboni A, Cerulli G, Perugini M, Iannetti G. Mandibular ameloblastoma: analysis of surgical treatment carried out in 60 patients between 1977 and 1998. J Craniofac Surg 2002; 13(3):395-400.

[7]. Ferretti C, Polakow R, Coleman H. Recurrent ameloblastoma: report of 2 cases. J Oral Maxillofac Surg 2000; 58(7):800-4.

[8]. Hollows P, Fasanmade A, Hayter JP. Ameloblastoma - a diagnostic problem. Br Dent J 2000; 188(5):243-4.

[9]. Kim SG, Jang HS. Ameloblastoma: a clinical, radiographic and

[10]. histopathologic analysis of 71 cases. Oral Surg Oral Med Oral Pathol OralRadiol Endod 2001; 91(6):649-53.10 10 . Rosenstein T, Pogrel MA, Smith RA, Regezi JA. Cystic ameloblastoma

behaviour and treatment of 21 cases. J Oral Maxillofac Surg 2001;

[11]. 59(11):1311-6. Nakamura N, Higuchi Y, Mitsuyasu T, Sandra F, Ohishi M. Comparison of long-term results between different approaches to ameloblastoma. Oral Surg Oral Med Oral Pathol Oral Radiol Endod 2002; 93(1):13-20.

[12]. Martinez, C. R.; Barros, R. M. G.; Orué, N. R.; Oliveira, J. G. P. \& Monteiro, J. C. C. Ameloblastoma: estudo clínicohistopatológico. Rev. Cir. Traumatol. Buco-Maxilo-Fac., 8:55-60, 2008. [ Links ]

[13]. Cusak, J. W. Report of the amputation of the portions of the lower jaw. Dubin Hosp. Rep., 4:1-38, $1827 . \quad$ [ Links ]

[14]. Broca, P. Traité de tumeurs. Paris, Asselin, 1866. [ [ Links ]

[15]. Falkson, R. Zur Kenntnis der Kiefercysten. Virchows Arch. Pathol. Anat. Physiol. Klin. Med., 76:504-10, 1879. [ Links ]

[16]. Malassez, L. Sur le role des debris épithéliaux paradentaires. Arch. Physiol. Norm. Pathol., 5:309-40, 1885. [ [Links ]

[17]. Ivy, R. H. \& Churchil, H. R. The need of a standardized surgical and pathological classification of the tumors and anomalies of dental origin. Am. Assoc. Dent. Sch. Trans., 7:240-5, 1960. [ [ Links ]

[18]. Adekeye, E. O. \& Lavery, K. M. Recurrent ameloblastoma of the maxillo-facial region. Clinical features and treatment. J. Maxillofac. Surg., 14:153-7, $1986 . \quad$ [ Links ]

[19]. Antunes, A. A.; Silva, P. V.; Antunes, A. P. \& Romualdo Filho, J. Ameloblastoma: Estudo Retrospectivo. Rev. Bras. Cir. Cabeça Pescoço, 35:70-3, $2006 . \quad$ [ Links ]

[20]. Ord, R. A.; Blanchaert, R. H. Jr.; Nikitakis, N. G. \& Sauk, J. J. Ameloblastoma in Children. J. Oral Maxillofac. Surg., 60:762-71, 2002. [ Links ]

[21]. Bilkay U, Tokat C, Helvaci E, Ozek C and Alper M(2004). Free fibula flap mandible reconstruction in benign mandibular lesions. J Craniofac Surg,15(6):1002-1009. 
[22]. Mendenhall, W. M.; Werning, J. W.; Fernandes, R.; Malyapa, R. S. \& Mendenhall, N. P. Ameloblastoma. Am. J. Clin. Oncol., 30:645-8, 2007. [ [ Links ]

[23]. Pizer, M. E.; Page, D. G. \& Svirsky, J. A. Thirteen-year followup of large recurrent unicystic ameloblastoma of the mandible in a 15-year-old boy. J.Oral Maxillofac. Surg.,60:211-5, 2002

[24]. Anjos, E.; Andrade, E.; Pinto, L. \& Souza, L. Estudo clínicopatológico de ameloblastomas: análise de casos. Rev. Bras. Patol. Oral, 60:224-8, 2003. [ [ Links ]

[25]. Chana, Jagdeep S, Yang-Ming Chang, Wei, Fu-Chan, Shen, Yu-Fen, Chan Chiu-Po, Lin Hsiu-Na, Tsai Chi-Ying, Jeng SengFeng: Segmental mandibulectomyand immediate free fibula osteoseptocutaneous flapreconstruction with endosteal implants: An ideal treatment method for mandibular ameloblastoma.Plast Reconstr Surg 2004 , 113(1):80-87.9. Li TJ, Kitano M, Arimura K, Sugihara K: Recurrence

[26]. Derderian CA, Gurtner GC and McCarthy JG (2004).Reconstruction of a large mandibular defect utilizing temporary zygomaticramal fixation and bilateral Risdon incisions. J Craniofac Surg, 15(1): 16-19.Disa JJ and Cordeiro PG (2000). Mandible reconstruction with microvascular surgery. Semin Surg Oncol, 19(3): 226-234.

[27]. A Kahairi ,Rl Ahmed a , L Wan Islah, H Noma Archives of Orofacial Sciences (2008), 3(2): 52-55. Case report "management of large ameloblastoma a case report \& literature review

[28]. Eppley BL (2002). Re: Mandibular ameloblastoma:analysis of surgical treatment carried out in 60patients between 1977 and 1998. J Craniofac Surg,13(3): 400.

[29]. Ghandhi D, Ayoub AF, Pogrel MA, MacDonald G, Brocklebank LM, Moos KF.Ameloblastoma: a surgeon's dilemma. J Oral Maxillofac Surg 2006;64:1010-4. 